\title{
First records of Croaking Gourami, Trichopsis vittata (Cuvier, 1831) (Teleostei: Osphronemidae), from Myanmar and Bangladesh
}

\author{
Michael Norén, ${ }^{1}$ Sven O. Kullander, ${ }^{1}$ Md. Mizanur Rahman ${ }^{2}$, Abdur Rob Mollah ${ }^{2}$
}

1 Department of Zoology, Swedish Museum of Natural History, P.O. Box 50007, SE-104 05, Sweden. 2 Department of Zoology, University of Dhaka, Dhaka-1000, Bangladesh.

Corresponding author: Michael Norén, michael.noren@nrm.se

\begin{abstract}
The Croaking Gourami, Trichopsis vittata (Cuvier, 1831), is native to Southeast Asia and Sundaland, with introductions reported from USA, Philippines and India. The species was found by us in Myanmar (1997 and 2013), and Bangladesh (2014 and 2016). DNA analysis supports the view that $T$. vittata is a species complex. Specimens from Bangladesh, Myanmar and the European aquarium trade are the same genotype as specimens from Thailand, possibly corresponding to Trichopsis harrisi Fowler, 1934, considered a synonym of T. vittata. Non-native populations are likely due to release from aquarium specimens.
\end{abstract}

\section{Key words}

DNA barcode; COI; ornamental fish; invasive species; Bangladesh; Myanmar.

Academic editor: Zeehan Jaafar | Received 13 January 2017 | Accepted 16 May 2017 | Published 12 July 2017

Citation: Norén M, Kullander SO, Rahman MM, Mollah, AR (2017) First records of Croaking Gourami, Trichopsis vittata (Cuvier, 1831) (Teleostei: Osphronemidae), from Myanmar and Bangladesh. Check List 13 (4): 81-85. https://doi.org/10.15560/13.4.81

\section{Introduction}

Trichopsis vittata (Cuvier, 1831), known as Croaking Gourami in the ornamental fish trade, is a small airbreathing osphronemid fish, reported as native from Java, Borneo, Sumatra, Peninsular Malaysia, Thailand, and the Mekong basin in Cambodia, Laos, and Vietnam (Kottelat 1985, Rainboth 1996, Baird et al. 1999). Trichopsis vittata is found in shallow, slow-flowing or stagnant waters with abundant vegetation, such as rice fields, roadside ditches, and irrigation canals. It is able to survive in brackish water up to 20 psu salinity, and in temperatures down to $7.2{ }^{\circ} \mathrm{C}$ (Schofield and Schulte 2016). It feeds on small planktonic crustaceans and insect larvae (Rainboth 1996). The male is territorial and builds a small inconspicuous bubble nest among the vegetation, in which the eggs are deposited and guarded by the male until the larvae become free-swimming (Britz et al. 2001, Liengpornpan et al. 2006). Due to its small size there is no targeted fishery for T. vittata, but it is occasionally sold in markets as part of mixed catches, and is regularly seen in the ornamental fish trade (Rainboth 1996).

The FAO Introduction of Species database lists $T$. vittata as introduced only to the USA, where a feral population has persisted in southern Florida since the 1970s (Lee et al. 1980, Schofield and Pecora 2013), but established feral populations of T. vittata have also been reported from the Philippines (BFAR 2006), without supporting data, and most recently from Chennai in Tamil Nadu, India (Knight and Balasubramanian 2015). Here 
we present additional localities from Myanmar and Bangladesh, up to $1000 \mathrm{~km}$ west of the natural range of the species and $1500 \mathrm{~km}$ northeast of the previously known feral population in Chennai, and discuss the origin and future development of feral T. vittata in South Asia.

\section{Methods}

All vouchered localities in Myanmar and Bangladesh are presented in Table 1 and mapped in Figure 1. All listed specimens were collected using beach seine or handheld nets, or purchased at fish markets, and morphologically identified. The standard barcoding region of the mitochondrial cytochrome $c$ oxidase subunit I (COI) gene was sequenced from 5 T. vittata collected in Bangladesh, 6 collected in Myanmar, and 3 aquarium specimens (GenBank accession numbers: KT250366, KY327366, KY327367) purchased in Sweden, using the primers and protocol of Ward et al. (2005).

The obtained DNA sequences were assembled in Geneious version 9 (KEARSE et al. 2012), and combined with all $134 \mathrm{COI}$ sequences identified as $T$. vittata, $T$. cf. vittata, or $T$. sp. cf. vittata deposited on GenBank, to produce a matrix from which to estimate sequence divergence as pairwise p-distance, the percentage of differing nucleotide sites between 2 compared DNA sequences (please note that this is a simple measure of dissimilarity and different from the similarly-named statistical term $p$-value). A neighbor-joining majority rule bootstrap tree (Jukes-Cantor model, 500 repetitions, random addition sequence) rooted with Betta macrostoma (GenBank Accession number KM485437) was produced to visualize genetic similarity (not shown) The Identification tool of the Barcode of Life portal (http://boldsystems.org) was used to obtain the Barcode of Life Barcode Index Numbers (BINs) of clusters of similar published sequences, corresponding to putative species. Voucher specimens are deposited in the collections of Dhaka University and the Swedish Museum of Natural History.

Published occurrence data used to construct occurrence map (Fig. 2) were obtained from the Academy of Natural Sciences at Philadelphia, Auburn University Museum of Natural History, California Academy of Sciences, Field Museum, Florida Fish and Wildlife Conservation Commission, Illinois Natural History Survey, GBIF-MNHN (Paris), Oregon State University, Royal Ontario Museum, Florida Museum of Natural History, University of Michigan Museum of Zoology, United States National Museum of Natural History, Smithsonian Institution, Yale University Peabody Museum, and Natural History Museum of Denmark (Accessed through the Fishnet2 Portal, http:www.fishnet2.net, 2015-5-26).

Collecting was made with permission from the Department of Environment in Bangladesh to the Department of Zoology, University of Dhaka, and from the Department of Fisheries in Myanmar to Swedish teams.

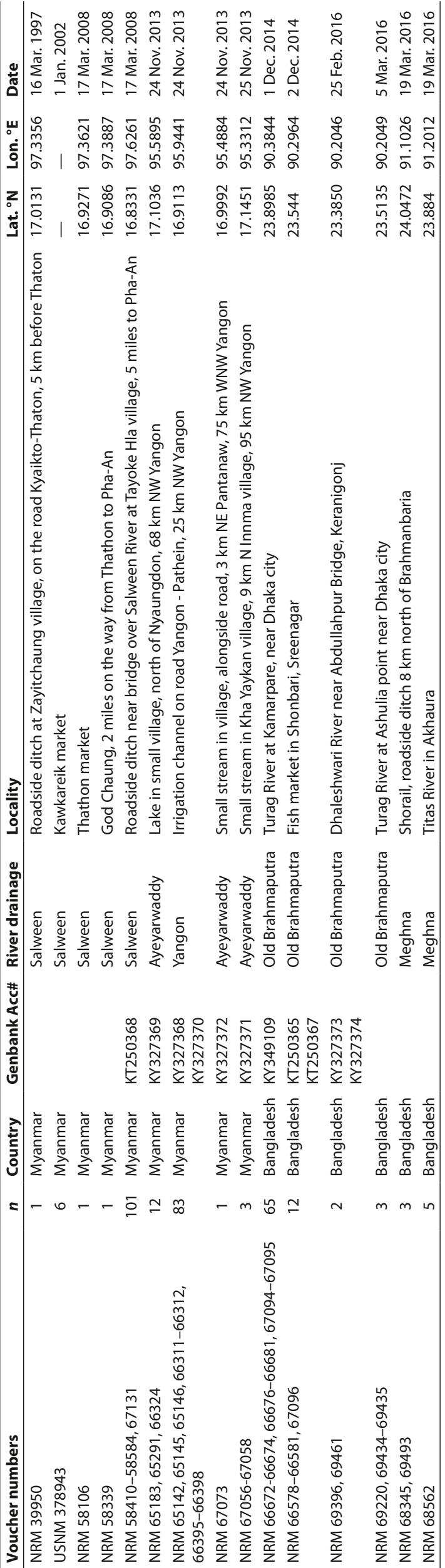




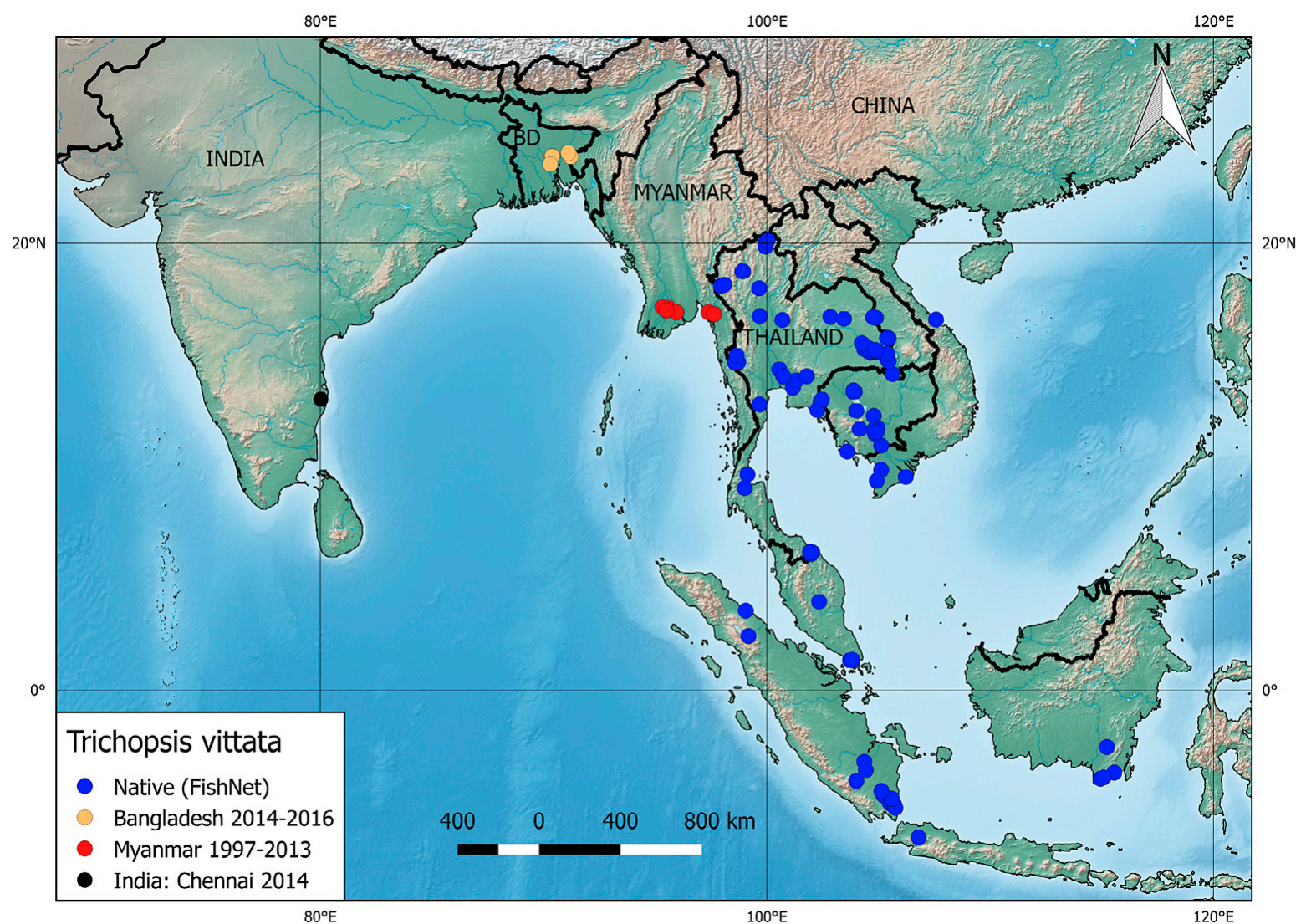

Figure 1. Distribution of Trichopsis vittata in Asia, based on occurrence records in FishNet II (1906-2014), Knight and Balasubramanian (2015), and University of Dhaka and Swedish Museum of Natural History records (Myanmar 1997-2013; Bangladesh 2014, 2016). BD = Bangladesh.

\section{Results}

Trichopsis vittata can be separated from the 2 other currently recognized species in the genus, Trichopsis pumila (Arnold, 1936) and Trichopsis schalleri Ladiges, 1962, by the presence of a thin dark line below the eye. Trichopsis vittata also grows to a larger maximum size, and normally has 3 longitudinal dark bands on the posterior half of the body instead of 2 as in T. schalleri and T. pumila (in $T$. pumila the upper of the 2 bands is broken into a row of dark spots surrounded by iridescent scales) (Fig. 2). Rainboth (1996) states that T. vittata grows up to $70 \mathrm{~mm}$ standard length (SL). Sithtananan (2010) measured 848 individuals from all over the native distribution and found a maximum length of $48.8 \mathrm{~mm} \mathrm{SL}$, and average length $31 \mathrm{~mm}$ SL.

\section{Discussion}

There are no published records of $T$. vittata from Bangladesh or Myanmar previous to the present report, not even from the Myanmar portion of the Mekong River, but the species has been common in collections from Indochina and Indonesia for more than a century, suggesting that the Tenasserim and Sino-Burman ranges separating the Indochinese watersheds from the Burmese have been a barrier to westward dispersal (Fig. 1). In 1997, staff from the Swedish Museum of Natural History collected a single $T$. vittata from a roadside ditch $5 \mathrm{~km}$ north of the town of Thaton, in Mon State in eastern Myanmar.
The individual was a juvenile, showing that the species was already reproducing in the region. In 2008, numerous specimens were collected at different localities in Kayin State in eastern Myanmar, and in 2013 we found numerous specimens at different localities in southern

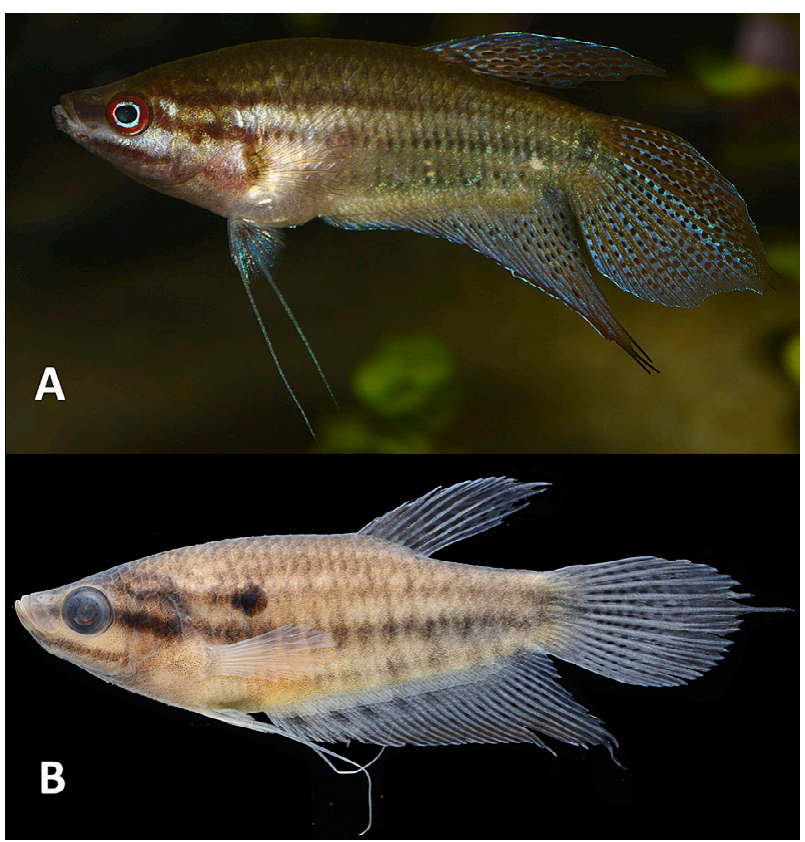

Figure 2. Trichopsis vittata. A. Live male specimen photographed in aquarium (not preserved), B. Preserved specimen (NRM67094c), $32.8 \mathrm{~mm} \mathrm{SL}$, collected from Turag River, Bangladesh, 2014. The dark pigmented line below the eye is a diagnostic character for T. vittata. 
Myanmar west of the city of Yangon, and additional specimens were obtained in the Kawkareik district in eastern Myanmar by Mr. U Tin Win. The earliest records of $T$. vittata from Myanmar are from the eastern part of the country, but no collections are available from the same time in western Myanmar, so the dispersal within Myanmar should not be assumed to have been from east to west. In 2014 we found the species in abundance in the Turag River, a tributary of the lower Brahmaputra flowing through Dhaka, and at the fish market in the nearby Sreenagar (Dhaka Division) in central Bangladesh (Table 1). The species was recorded again in 2016 from the Turag River, and also in the nearby Dhaleswari River as well as 2 localities in the lower Meghna River northeast of Dhaka (Table 1). No T. vittata were found in southeastern Bangladesh (Chittagong Division) during a survey in 2015, or in northeastern Bangladesh (Sylhet Division), surveyed in 2016, despite the presence of suitable habitat.

Panijpan et al. (2015) analyzed mitochondrial COI and nuclear RAG1 DNA sequences of a large number of Trichopsis from Southeast Asia, and found that T. vittata is not a single species but a species complex comprising 4 ecologically and morphologically similar but genetically distinct biological species. However, there were no DNA sequences available from Java, the type locality of T. vittata (Roberts 1996), and Panijpan et al. (2015) were unable to determine which, if any, of these 4 clades represented the true $T$. vittata. Dahruddin et al. (2016) published 6 sequences of T. vittata from Java, which in our analysis correspond to the clade that Panijpan et al. (2015) referred to as "Trichopsis cf. vittata 4", from southern Thailand (BIN cluster ID BOLD:AAB9368).

As a coarse empirical rule-of-thumb, for the COI gene, the dissimilarity between any 2 members of the same species is typically $<1 \%$, while the dissimilarity between members of different species is typically $\geq 2 \%$ (Ward 2009). This disjunct distribution of genetic similarity has been termed "the barcode gap" (Meyer and Paulay 2005), and can be used as an indicator of species affinity through a so-called barcode analysis, where a DNA sequence from an unidentified specimen is compared to a database of corresponding DNA sequences from wellidentified specimens, allowing confident identification also of single unknown sequences.

The COI sequences of $T$. vittata from Myanmar, Bangladesh, and the ornamental fish trade are similar ( $\leq 0.6 \% p$-distance) to each other and to 78 published COI sequences, corresponding to a clade Panijpan et al. (2015) referred to as "Trichopsis sp. (cf. vittata) 3" (BIN cluster ID BOLD:ACS9775), from western and central Thailand, but dissimilar ( $>2.4 \% p$-distance) to all individuals of $T$. vittata from other areas. This supports the conclusion by Panijpan et al. (2015) that the current $T$. vittata is a species complex, and indicates that $T$. vittata sold in the ornamental fish trade in Europe and the introduced populations in Bangladesh and Myanmar all originates from central and western Thailand. According to Panijpan et al. (2015), "Trichopsis sp. (cf. vittata) 3" is distributed in Thailand from Chiang Mai in the northwest, to Trat in the southeast, and Surat Thani in the south. Fowler (1934) described T. harrisi from Kratt (Trat), but Kottelat (2001) considered T. harrisi a junior synonym of T. vittata. A taxonomic revision of Trichopsis is needed, and may come to the conclusion that the correct name for "Trichopsis sp. (cf. vittata) 3" is T. harrisi.

The probable source of the feral population of $T$. vittata in Florida is a nearby ornamental fish farm, and also in the other locations the presumed source is release of ornamental fish (Schofield and Pecora 2013, Knight and Balasubramanian 2015). However, while Thailand is a major exporter of ornamental fish, and $T$. vittata does occur in the ornamental fish trade, it is not common. Pygmy gourami (T. pumila) is the most common species of Trichopsis in the ornamental fish trade, but feral populations have only been reported from the Philippines (BFAR 2006), without data. This suggests either that $T$. vittata is able to colonize new territory even when propagule size and frequency are low, or that it spreads also through some mechanism other than release of aquarium fish, such as intentional release for biological control of mosquitos or as a contaminant among shipments of live fish for aquaculture.

Wongsiri (1982) found that in Thailand the 3 most important fish predators of mosquito larvae were $T$. vittata, Guppy (Poecilia reticulata Peters, 1859) and Tilapia (Oreochromis sp.). The ability of T. vittata to survive in very small volumes of water, and to tolerate polluted or low-oxygen water, could make it suitable for mosquito control, but we can find no record of it having been intentionally released as a mosquito control agent.

Another possible avenue for introduction is as a contaminant in shipments of live aquaculture fish. The small East Asian Topmouth Gudgeon, Pseudorasbora parva (Temminck \& Schlegel, 1846), was introduced to Eastern Europe as a contaminant with fingerlings of Chinese cyprinids imported for aquaculture trials and has since spread to many river systems in Europe (Gavriloaie et al. 2008). In Asia, T. vittata could spread as a contaminant in shipments of for instance live Silver Barb, Barbonymus gonionotus (Bleeker, 1849), native to Southeast Asia, sympatric with $T$. vittata, and an important aquaculture species in South and Southeast Asia (Gupta and Rab 1994), but both Myanmar and Bangladesh have a range of cultured species (Siddiqui et al. 2007) which present similar potential. Nevertheless, the records from India, Myanmar and Bangladesh are close to major cities, where aquarium releases are more likely, and in the absence of evidence that $T$. vittata spreads as a contaminant, and considering that the feral populations are genetically similar to specimens from the aquarium trade, we consider the release of specimens from the aquarium trade the most probable mechanism of introduction.

Trichopsis vittata has many of the traits typical of efficient invaders: it is able to tolerate polluted or low oxygen conditions, is human-associated (through aquaria, rice fields, and its ability to survive in degraded habitats), 
has a short generation time, guards its eggs (uniparental care), and has a prior history of successful invasions. The preferred habitat of $T$. vittata (shallow, often temporary, vegetated waters with seasonal floods) corresponds to all areas suitable for rice-production, suggesting that it could potentially colonize most of southern and eastern Asia. However, T. vittata does not have any mechanism for long-distance dispersal, as it is non-migratory and does not have planktonic eggs or larvae, and non-human mediated spread is likely to be slow. In addition, it may locally be limited by life-history variables or interactions with the native biota, as seems to be the case with the population in Florida (Schofield and Schulte 2016).

No negative effects resulting from introduction of $T$. vittata have been reported, but Knight and Balasubramanian (2015) speculated that in India it may compete for niche space with native small osphronemids such as Dwarf Gourami [Trichogaster lalius (Hamilton, 1822)] and Spiketail Paradisefish [Pseudosphromenus cupanus (Cuvier, 1831)]. Other potential negative effects include aggressive displacement of native species, or that it may act as a vector for non-native parasites or pathogens, such as the trematode Euclinostomum heterostomum (Rudolphi, 1809) (Purivirojkul and Sumontha 2013).

\section{Acknowledgements}

This study is part of the project "Genetic characterization of freshwater fishes in Bangladesh using DNA barcodes" (Swedish Research Council, contract D0674001 to Sven Kullander and Abdur Rob Mollah).

\section{Authors' Contributions}

All authors contributed to collection and text. MN and MR extracted and sequenced DNA. MN made the analyses. SOK made images and table.

\section{References}

Baird IG, Inthaphaisy V, Kisouvannalath P, Phylavanh B, Mounsouphom B (1999) The fishes of southern Lao. Lao Community Fisheries and Dolphin Protection Project. Ministry of Agriculture and Forestry, Lao PDR, $161 \mathrm{pp}$.

BFAR (2006) List of Ornamental Fish Species Introduced to the Philippines through NAIA. Unpublished. [From Fishbase, not seen].

Britz R, Cambray JA (2001) Structure of egg surfaces and attachment organs in anabantoids. Ichthyological Exploration of Freshwaters 12 (3): 267-288.

Cuvier G, Valenciennes A (1831) Histoire naturelle des poissons. Tome 7. Paris, F.G. Levrault, 531 pp.

Dahruddin H, Hutama A, Busson F, Sauri S, Hanner R, Keith P, Hadiaty R, Hubert N (2016) Revisiting the ichthyodiversity of Java and Bali through DNA barcodes: taxonomic coverage, identification accuracy, cryptic diversity and identification of exotic species. Molecular Ecology Resources 17: 288-299. https://doi. org/10.1111/1755-0998.12528

Fowler HW (1934) Zoological results of the third De Schauensee Siamese Expedition, Part V. - Additional fishes. Proceedings of the Academy of Natural Sciences of Philadelphia 86: 335-352

Gavriloaie I-C, Falka I, Bucur C (2008) The most important Romanian researches on species Pseudorasbora parva (Temminck \& Schle- gel, 1846) (Teleostei, Cyprinidae). AACL Bioflux 1: 117-122

Gupta MV, Rab MA (1994) Adoption and economics of silver barb (Puntius gonionotus) culture in seasonal waters in Bangladesh. ICLARM Technical Reports 41: 39 pp.

Kearse M, Moir R, Wilson A, Stones-Havas S, Cheung M, Sturrock S, Buxton S, Cooper A, Markowitz S, Duran D, Thierer T, Ashton B, Mentjies P, Drummond A (2012) Geneious Basic: an integrated and extendable desktop software platform for the organization and analysis of sequence data. Bioinformatics 28 (12): 1647-1649. https://doi.org/10.1093/bioinformatics/bts199

Knight JDM, Balasubramanian S (2015) On a record of two alien fish species (Teleostei: Osphronemidae) from the natural waters of Chennai, Tamil Nadu, India. Journal of Threatened Taxa 7 (3): 7044-7046. https://doi.org/10.11609/JoTT.o4135.7044-6

Kottelat M (1985) Fresh-water fishes of Kampuchea. Hydrobiologia 121 (3): 249-279.

Kottelat M (2001) Fishes of Laos. WHT Publications, Colombo, 198 pp. Lee DS, Gilbert CR, Hocutt CH, Jenkins RE, McAllister DE, Stauffer JR Jr (1980) Atlas of North American Freshwater Fishes. North Carolina State Museum of Natural History, Raleigh, NC, 854 pp.

Liengpornpan S, Jaroensutasinee M, Jaroensutasinee K (2006) Mating habits and nesting habitats of the croaking gourami Trichopsis vittata. Acta Zoologica Sinica 52 (5): 846-853.

Meyer CP, Paulay G (2005) DNA barcoding: error rates based on comprehensive sampling. PLoS Biology 3 (12): e422. https://doi. org/10.1371/journal.pbio.0030422

Panijpan B, Laosinchai P, Senapin S, Kowasupat C, Ruenwongsa P, Kühne J, Phiwsaiya K (2015) Mitochondrial COI and nuclear RAG1 DNA sequences and analyses of specimens of the three morphologically established species in the genus Trichopsis (Perciformes: Osphronemidae) reveal new/cryptic species. Meta Gene 4: 17-28. https://doi.org/10.1016/j.mgene.2015.02.003

Purivirojkul W, Sumontha M (2013) Euclinostomum heterostomum (Rudolphi, 1809) Metacercarial infection in three osphronemid fish species. Walailak Journal of Sciences and Technology 10 (1): 97-102.

Rainboth WJ (1996) Fishes of the Cambodian Mekong. FAO Species Identification Field Guide for Fishery Purposes. FAO, Rome, 265 pp.

Roberts T (1996) The freshwater fishes of Java, as observed by Kuhl and van Hasselt in 1820-23. Zoologische Verhandelingen 285: 1-94.

Schofield P.J., D.J. Pecora. 2013. Croaking gourami, Trichopsis vittata (Cuvier, 1831), in Florida, USA. BioInvasions Records 2(3): 247-251. https://doi.org/10.3391/bir.2013.2.3.12

Schofield PJ, Schulte JM (2016) Small but tough: What can ecophysiology of croaking gourami Trichopsis vittata (Cuvier, 1831) tell us about invasiveness of non-native fishes in Florida? NeoBiota 28: 51-65. https://doi.org/10.3897/neobiota.28.5259

Siddiqui KU, Islam MA, Kabir SMH, Ahmad M, Ahmed ATA, Rahman AKA, Haque EU, Ahmed ZU, Begum ZNT, Hasan MA, Khondker M, Rahman MM (Eds) (2007) Encyclopedia of Flora and Fauna of Bangladesh. Vol. 23. Freshwater Fishes. Asiatic Society of Bangladesh, Dhaka, 300 pp.

Sithtananan P (2010) Taxonomic review of the anabantoid fish genus Trichopsis Canestrini, 1860 from Indochina (Perciformes: Osphronemidae). Master's thesis, Kasetsart University Research and Development Institute, Thailand, 158 pp. http:/www.lib.ku.ac.th/ KUthesis/2553/Pathteera-SIT/Pathteera-SIT-all.pdf. Accessed on: 2015-4-7.

Ward RD, Zemlak TS, Innes BH, Last PR, Hebert PD (2005) DNA barcoding Australia's fish species. Philosophical Transactions of the Royal Society B: Biological Sciences 360 (1462), 1847-1857. https://doi.org/10.1098/rstb.2005.1716

Ward RD (2009) DNA barcode divergence among species and genera of birds and fishes. Molecular Ecology Resources 9: 1077-1085. https://doi.org/10.1111/j.1755-0998.2009.02541.x

Wongsiri S (1982) Preliminary survey of the natural enemies of mosquitoes in Thailand. Journal of the Science Society of Thailand 8: $205-213$. 